\title{
KUALITAS PELAYANAN DI PERSEROAN TERBATAS PEGADAIAN (PERSERO) CABANG PALANGKARAYA
}

\author{
The Quality of service at the company's Pawnshop Limited (Persero) \\ Palangkaraya Branch
}

\section{Sabirin Muhtar*}

Hini Fitriya

Universitas Muhammadiyah

Palangkaraya, Palangka Raya, Central

Kalimantan, Indonesia

email:

sabirin.muhtar@umpalangkaraya.ac.id

Kata Kunci:

Kualitas Pelayanan

Keywords:

Quality of Service

\section{Accepted}

January 2015

Published

April 2015

\begin{abstract}
Abstrak
Penelitian ini bertujuan untuk mengetahui pelaksanaan dan faktor-faktor apa saja yang menjadi penghambat dan pendukung dalam Kualitas Pelayanan pada Perseroan TerbatasPegadaian (persero) cabang Palangkaraya Kalimantan Tengah. Tipe penelitian yang digunakan adalah metode penelitian kualitatif dengan tehnik analisis deskriptif. Kedudukan peneliti dalam penelitian kualitatif, peneliti merupakan perencana, pelaksana pengumpul data, analisis, penafsir data dan pada akhirnya peneliti menjadi pelapor hasil penelitiannya. Sumber data dalam penelitian ini adalah pegawai Perseroan Terbatas Pegadaian (persero) cabang Palangkaraya yang melayani nasabah dan nasabah.

Berdasarkan hasil penelitian dapat dijelaskan bahwa pelayanan pada Perseroan TerbatasPegadaian (Persero) Cabang Palangkaraya Kalimantan Tengah, faktor penghambat yang ditemui (I) Banyaknya keluhan dari Nasabah tentang ketepatan waktu yang mengakibatkan kualitas pelayanan pada Perseroan Terbatas. Pegadaian (Persero) Cabang Palangkaraya masih belum berkualitas. (2) Akurasi pelayanan yang kurang baik, karena masih ada pegawai yang kurang teliti dalam bertransaksi kepada nasabah. (3) Sikap yang sopan dan ramah yang diberikan oleh petugas Perseroan TerbatasPegadaian (persero) cabang Palangkaraya kepada masyakarat. (4) masih kurangnya kemudahan dalam pelayanan sehingga nasabah merasa dipersulit dalam berurusan di Perseroan Terbatas Pegadaian (Persero) Cabang Palangkaraya. (5) masih kurang mendukungnya sarana dan prasarana yang ada. (6) masih kurangnya partisipasi kepada masyarakat.
\end{abstract}

\begin{abstract}
This research aims to determine the implementation and factors that become a barrier and supporter in the quality of service in the company's local pawnshop (Persero) Palangkaraya branch of central Kalimantan. The type of research used is qualitative research methods with descriptive analytical techniques. Researcher's position in qualitative research, the researcher is a planner, Data collector Executor, analysis, data interpreter and eventually, researchers become the reporter of the results of his research. The data source in this study is the employees of the company's limited pawnshop (Persero) Palangkaraya branch that serves customers and customers.

Based on the results of the research can be explained that the service of the company's pawnshop (Persero) Palangkaraya Branch Central Kalimantan, a barrier factor encountered $(I)$ the number of complaints from the customer about the timeliness that resulted in Quality of service to limited liability company. Pawnshop (Persero) Palangkaraya Branch still not quality. (2) Accuracy of service is not good, because there are still employees who are less thorough in the transaction to the customer. (3) Polite and friendly attitude given by the officers of the limited liability company (Persero) Palangkaraya branch to the community. (4) is still a lack of convenience in service so that customers feel complicated in dealing in the company of Pawnshop Limited (Persero) Palangkaraya branch. (5) Still lacks the support of existing facilities and infrastructures. (6) Still, lack of participation in the community.
\end{abstract}

\section{PENDAHULUAN}

Era globalisasi sekarang ini, menuntut Badan Usaha Milik Negara (BUMN) untuk meningkatkan pelayanan secara profesional sesuai dengan bidangnya masingmasing. Perubahan tekhnologi dan arus informasi yang sangat cepat telah mendorong perusahaan untuk 
menghasilkan produk atau layanan yang dapat memenuhi kebutuhan dan keinginan konsumen, sehingga konsumen merasa puas dengan apa yang telah mereka dapatkan dari perusahaan tersebut. Banyak cara yang dapat dilakukan perusahaan dalam memenuhi kebutuhan dan keinginan konsumen, salah satunya yaitu dengan memberikan kesan / citra yang baik dalam hal produk maupun pelayanan kepada konsumen. Badan Usaha Milik Negara (BUMN) yang ada di Indonesia sangat berpengaruh dalam perkembangan dunia usaha dan masyarakat dalam menjalankan usahanya, karena kebanyakan perusahaan dari milik pemerintah tersebut telah memonopoli beberapa bidang usaha yang mengatur kehidupan dan kebutuhan hidup masyarakat banyak. Oleh karena itu, dalam mengatur dan menjalankan usahanya BUMN diatur dan dikelola oleh pemerintah karena sangat berhubungan dengan nasib masyarakat Indonesia. Badan-Badan Usaha Milik Negara tersebut, diharapkan dapat memenuhi kebutuhan dan keinginan dari dunia usaha pada umumnya dan masyarakat pada khususnya dan harus dapat mempertahankan citra yang baik di mata Masyarakat.

BUMN harus dapat memberikan kepuasan kepada masyarakat selaku konsumen dan memberikan citra yang baik di mata masyarakat dengan cara memberikan pelayanan yang berkualitas. Melihat keadaan tersebut, pemerintah berupaya agar BUMN berusaha dapat memperbaiki keadaan dengan memberikan pelayanan yang terbaik kepada masyarakat. Dengan pelayanan yang baik, diharapkan masyarakat akan merasa dihargai dan tidak merasa di abaikan haknya dan akhirnya masyarakat sebagai pengguna atau pelanggan dari jasa yang ditawarkan oleh perusahaan milik pemerintah tersebut akan merasa puas.

Perseroan Terbatas Pegadaian (Persero) merupakan salah satu Perusahaan Milik Negara yang memberikan pelayanan kepada calon pelanggan dan masyarakat dalam penyediaan jasa. Pola kerjanya adalah pihak
Pegadaian menyediakan dan menyalurkan uang pinjaman dengan jaminan barang bergerak (Burhannudin, 2010:175) bagi masyarakat yang membutuhkan dana dengan segera, adapun masyarakat menjadikan harta bendanya sebagai jaminan (Barang Gadaian). Dalam melakukan kegiatannya Perseroan Terbatas Pegadaian (Persero) menyediakan bagian pelayanan pelanggan yang tugasnya memberikan pelayanan yang dibutuhkan oleh setiap masyarakat.

Prosedur untuk memperoleh kredit gadai sangat sederhana, masyarakat hanya menunjukkan bukti identitas diri dan barang bergerak sebagai jaminan, uang pinjaman dapat diperoleh dalam waktu yang tidak relatif lama ( kurang lebih 15 menit). Begitupun untuk melunasi pinjaman, nasabah cukup dengan menyerahkan sejumlah uang dan surat bukti Gadai dengan waktu proses yang juga singkat.

Adapun permasalahan yang terjadi di Perseroan Terbatas Pegadaian (Persero) Cabang Palangkaraya antara lain berkurangnya jumlah nasabah dan kurangnya sarana dan prasarana yang memadai.

Menurut Ibrahim (Hardiyansyah 2008:14), bahwa pemerintah/pemerintahan sudah seharusnya menganut paradigma custumer driven (berorientasi kepentingan masyarakat) dalam memberikan pelayanan kepada masyarakat luas. Untuk itu diperlukan aturan main yang tegas, dan adaptif terhadap tuntutan perkembangan lingkungan, yang cirinya selalu berubah dengan cepat dan kadang penuh ketidak pastian. Di sinilah terletak seni dan ilmu pelayanan yang harus dikembangkan pemerintah bersama seluruh lapisan masyarakat (dalam administrasi publik, harus ada integrasi dalam hal melaksanakan pelayanan publik yang berkualitas) antara seluruh pembangunan, yakni antara sektor pemerintahan dan sektor swasta dan sektor masyarakat luas lainnya.

Menurut Tjiptono (Hardiyansyah, 2008:40) menentukan kualitas pelayanan dapat di ukur dari indikator sebagai berikut: 
I. Ketepatan waktu pelayanan, yang meliputi waktu tunggu dan waktu proses;

2. Akurasi pelayanan, yang meliputi bebas dari kesalahan;

3. Kesopanan dan keramahan dalam memberikan pelayanan;

4. Kemudahan mendapatkan pelayanan, misalnya banyaknya petugas yang melayani dan banyaknya fasilitas pendukung seperti komputer;

5. Kenyamanan dalam memperoleh pelayanan, berkaitan dengan lokasi, ruang tempat pelayanan, tempat parkir, ketersediaan informasi dan lain-lain;

6. Atribut pendukung pelayanan lainnya seperti ruang tunggu ber-AC, kebersihan dan lain-lain.

Pelayanan Pegadaian mengandung dari unsur-unsur Budaya Kerja INTAN, dengan mottonya "Mengatasi Masalah Tanpa masalah". Motto tersebut menjadi cerminan dari tujuan dan cara kerja yang akan diterapkan di Perseroan Terbatas Pegadaian (Persero). Melalui motto tersebut disampaikan melalui budaya intan tersebut ditanamkan pada setiap insan pegadaian sehingga tujuan, visi dan misi perusahaan dapat tercapai.

Pelayanan pada dasarnya dapat didefinisikan sebagai aktivitas seseorang, sekelompok dan/atau organisasi baik langsung maupun tidak langsung untuk memenuhi kebutuhan. Menurut Moenir (Pasolong 2007:128), mengatakan bahwa pelayanan adalah proses pemenuhan kebutuhan melalui aktivitas orang lain secara langsung. Lebih lanjut, Pelayanan Publik menurut Sinambela (Pasolong, 2007:128), adalah sebagai setiap kegiatan yang dilakukan oleh pemerintah terhadap sejumlah manusia yang memiliki setiap kegiatan yang menguntungkan dalam suatu kumpulan atau kesatuan, dalam menawarkan kepuasan meskipun hasilnya tidak terikat pada suatu produk secara fisik.

\section{METODOLOGI}

Untuk mengungkapkan mengenai kualitas pelayanan di Perseroan Terbatas Pegadaian (Persero) Cabang Palangka Raya, maka peneliti menggunakan metode penelitian Kualitatif / deskriptif memuat Sugiyono (2013:13) dalam Metode Penelitian menyatakan bahwa: Metode penelitian kualitatif / deskriptif adalah metode penelitian yang berlandaskan pada filsafat positivisme, digunakan untuk meneliti pada kondisi objek yang alamiah, (sebagai lawannya adalah eksperimen dimana peneliti sebagai intrument kunci, pengambilan sampel sumber data dilakukan secara (gabungan), analisis data bersifat induktif/kualitatif, dan hasil penelitian kualitatif lebih menekankan makna dari pada generalisasi.

\section{HASIL DAN PEMBAHASAN}

Dari penelitian yang telah dilaksanakan dilapangan, maka penulis merasa ada beberapa hal yang perlu diperhatikan terkait tentang Kualitas Pelayanan di Kantor Perseroan Terbatas Pegadaian (Persero) Cabang Palangkaraya masih kurang baik untuk melaksanakan apa yang menjadi tugas dan tanggung jawab dari pegawai kantor Perseroan Terbatas Pegadaian (Persero) Cabang Palangkaraya.

Belum tercapainya kualitas pelayanan secara baik dapat disebabkan kurang baiknya pelayanan yang diberikan oleh pihak Kantor Perseroan Terbatas Pegadaian (Persero) Cabang Palangkaraya dan masih sering terjadi kendala dalam pelaksanaan pelayanan Publik.

I. Ketepatan Waktu

Dalam pelayanan seharusnya kita memberikan pelayanan sebaik mungkin agar nasabah merasa dilayani dengan baik. Disini masyarakat masih belum merasa dilayani dengan baik, karena masih adanya pegawai yang datang terlambat, tidak sesuai dengan jam kerja. Proses yang begitu lama tidak sesuai dengan standar operasional prosedur yang ada, di dalam standar 
operasional prosedur \pm 15 menit pelayanan selesai tetapi masih ada yang melebihi lebih dari 30menit. Ketepatan waktu yang memenuhi harapan nasabah yaitu petugas membuka loket pembayaran barang gadaian tepat pukul 08.00 WIB istirahat jam 12.00 WIB. Kembali lagi buka loket jam 13.00 WIB dan petugas menutup loket pembayaran barang gadaian tepat pukul 15.00 WIB. Yang belum memenuhi harapan nasabah adalah ketidaktepatan waktu petugas dalam melayani, pelayanan masalah nasabah lambat ditanggapi. Hal ini berarti nasabah belum merasa nyaman sehingga perlu dilakukan evaluasi dan perbaikan dalam pelayanan agar nasabah merasa nyaman bertransaksi di Perseroan Terbatas Pegadaian (Persero) Cabang Palangkaraya.

2. Akurasi pelayanan

Pelayanan yang dapat dipertanggung jawabkan sesuai dengan peraturan perundangundangan, meliputi kemampuan untuk memberikan pelayanan. Akurasi pelayanan Masih dirasakan kurang baik, karena ketidak telitian pegawai dalam memberikan barang gadaian kepada nasabah, menyimpan barang gadaian (emas), dan kasir yang tidak teliti dalam menghitung keuangan. Ketidak telitian itu misalnya dalam memberikan barang tebusan tidak sesuai dengan barang yang digadai, kurangnya memberi uang kembalian kepada nasabah, sehingga merugikan untuk nasabahnya sendiri akibat ketidak telitian kasir tersebut.

3. Kesopanan dan Keramahan

Memenuhi semua kebutuhan dan keperluan nasabah dalam pelayanan di kantor Perseroan Terbatas Pegadaian (Persero) Cabang Palangkaraya cukup baik. Cukup baiknya pegawai Perseroan Terbatas Pegadaian (Persero) Cabang Palangkaraya sebagian sudah ada yang ramah dalam melayani nasabah. Ketidak ramahan itu mengakibatkan nasabah kurang puas dalam pelayanan. Pelaksanaan pelayanan yang ada di kantor Perseroan Terbatas Pegadaian (Persero) sudah cukup sesuai prosedur yang sudah ditetapkan.

Keramahan pegawai adalah salah satu kunci untuk membuat nyaman nasabah yang berurusan di kantor Perseroan Terbatas Pegadaian (Persero) Cabang Palangkaraya, karena keramahan dan kesopanan pegawai dalam melayani nasabah dan masyarakat yang berurusan membuat mereka merasa tidak dibeda-bedakan dengan nasabah lain. Dari hal tersebut menunjukan bahwa pegawai Perseroan Terbatas Pegadaian (Persero) Cabang Palangkaraya cukup baik dalam melayani masyarakat/nasabah yang berurusan di kantor Perseroan Terbatas Pegadaian (Persero) Cabang Palangkaraya.

4. Kemudahan Pelayanan

Berdasarkan hasil penelitian dan pengamatan di lapangan kemudahan dalam pelayanan masih kurang, karena masih adanya nasabah yang merasa di persulit dalam gadai baru, dan penebusan barang. Di persulit dalam gadai baru misalnya persyaratan yang terlalu ribet seperti foto copy KTP, SIM, Kartu Keluarga dII. Sehingga nasabah merasa dipersulit dalam hal gadai baru. Di persulitnya dalam hal penebusan barang misalnya yang menggadai ibu nya, dan yang menggambil barang adalah anaknya padahal ibunya lagi berada diluar kota, penebusan tidak akan di transaksi apabila tidak dari orang yang bersangkutan yang datang untuk mengambil barang tersebut.

5. Kenyamanan memperoleh pelayanan

Berdasarkan hasil penelitian dan pengamatan di lapangan kenyamanan memperoleh pelayanan cukup baik. Ketersediaan tempat parkir yang sudah memadai, kenyamanan Nasabah memperoleh informasi dari berbagai media seperti televisi, surat kabar, majalah, dan radio. 
6. Atribut pendukung pelayanan

Berdasarkan hasil penelitian dan pengamatan di lapangan dalam segi atribut pengamatan sudah baik. Ruang tunggu yang bersih, ruangan yang ber-AC sudah membuat nasabah merasa nyaman.

\section{KESIMPULAN}

Dapat disimpulkan bahwa Kualitas Pelayanan di Perseroan Terbatas Pegadaian (Persero) cabang Palangkaraya sudah baik walalupun masih ada yang kurang baik. Agar lebih mengbaikkan peran serta dari kantor Perseroan Terbatas Pegadaian (Persero) Cabang Palangkaraya kepada nasabah, peneliti menyarankan beberapa hal sebagai berikut:

I. Diharapkan kepada pimpinan Perseroan Terbatas Pegadaian (Persero) Cabang Palangkaraya lebih tegas dan dapat memberikan teguran kepada para pegawai yang masih sering tidak tepat waktu dalam proses melayani nasabah, serta mematuhi Standar Operasional Prosedur yang telah ditetapkan.

2. Di harapkan kepada pegawai Perseroan Terbatas Pegadaian (Persero) Cabang Palangkaraya agar lebih teliti dalam hal transaksi kepada nasabah. Sehingga tidak ada yang merasa dirugikan dan hal yang tidak di inginkan terjadi.

3. Diharapkan juga kepada Perseroan Terbatas Pegadaian (Persero) Cabang Palangkaraya agar menyediakan nomor antrian agar nasabah patuh pada urutannya masing-masing.

\section{REFERENSI}

Hardiansyah, M.Si. Dr. 201 I kualitas pelayanan publik. Yogyakarta : Gava Media

Ibrahim, Amin. 2008. Teori dan konsep Pelayanan Publik serta Implementasinya.

Bandung: Mandar Maju.

Moenir, H.A.S. 2006. Manajemen Pelayanan Umum di Indonesia. Jakarta:

\section{Bumi Aksara}

Nogi, Hessel S. 2003. kebijakan publik yang membumi. Kerjasama: Lukman Offset \& yayasan pembaruan Administrasi Publik

Pasolong, Harbani. 2008. Teori Administrasi Publik. Bandung : Alfabeta.

Ratminto \& Atik Septi Winarsih. 2007. Manajemen Pelayanan. Yogyakarta: Pustaka Pelajar.

Sudrajat,Subana M. 2005. "Dasar-dasar Penelitian Ilmiah” Bandung : Pustaka Setia

Sugiyono. 2009. Metode Penelitian Pendidikan. Bandung : Alfabeta.

Suwhono. 2012. Standar Perusahaan Perseroan Terbatas .Pegadaian (Persero). Jakarta : Kantor pusat

Tjiptono, Fandy. 2000. Manajemen Jasa. Yogyakarta: Andi

Keputusan Menteri Negara Pemberdayaan Aparatur Negara Nomor 63/ KEP/M.PAN/7/2003 Tentang Pedoman Umum Penyelenggaraan Pelayanan Publik. 